\title{
The subtidal macrobenthos in the mesohaline part of the Schelde estuary (Belgium): influenced by man?
}

T.Ysebaert, L. De Neve and P. Meire

\section{Abstract}

The macrobenthos of the subtidal, mesohaline zone of the Schelde estuary (Belgium) was sampled in October 1996 and 1997 at 54 and 73 sampling locations respectively. Sediments ranged from silty to very coarse, with the dominant sediment type being silt (33\% of all locations). Of the 35 macrobenthic species observed, only seven species occurred in more than $20 \%$ of the samples. The polychaete Heteromastus filiformis and Oligochaeta were most common. Multivariate techniques revealed three distinct communities, linked mainly with sedimentological factors: ( 1 ) a species-poor ( 9 species) community with a dominance of the amphipod Bathyporeia pilosa, a low mean abun- dance and biomass ( 86 ind $\mathrm{m}^{-2}, 0.0189 \mathrm{~g}$ AFDW $\mathrm{m}^{-2}$ ), and a mean median grain size of $215 \pm 19 \mu \mathrm{m}$ (fine sand); (2) a species-rich (22) community, with the small polychaete Polydora ligerica as indicator species, a relatively high mean abundance and biomass (2298 ind $\mathrm{m}^{-2}, 1.395 \mathrm{~g}$ AFDW $\mathrm{m}^{-2}$, oysters excluded), a mean median grain size of 133 $\pm 4 \mathrm{I} \mu \mathrm{m}$, and also the occurrence of sediments with hard substrates being characteristic for this community; (3) a community with an intermediate species richness (12), abundance and biomass ( 248 ind $\mathrm{m}^{-2} ; 0.249 \mathrm{~g}$ AFDW $\mathrm{m}^{-2}$ ), with $H$. filiformis and Oligochaeta as indicator species, and a median grain size of $76 \pm 9 \mu \mathrm{m}$. In the study area several typical brackish water species were observed (e.g. Polydora ligerica, Corophium lacustre, Gammarus salinus).

Mean total abundance and biomass were very low, and the benthic communities appeared to be under stress, with a dominance of mainly small, sub-surface deposit and sur-

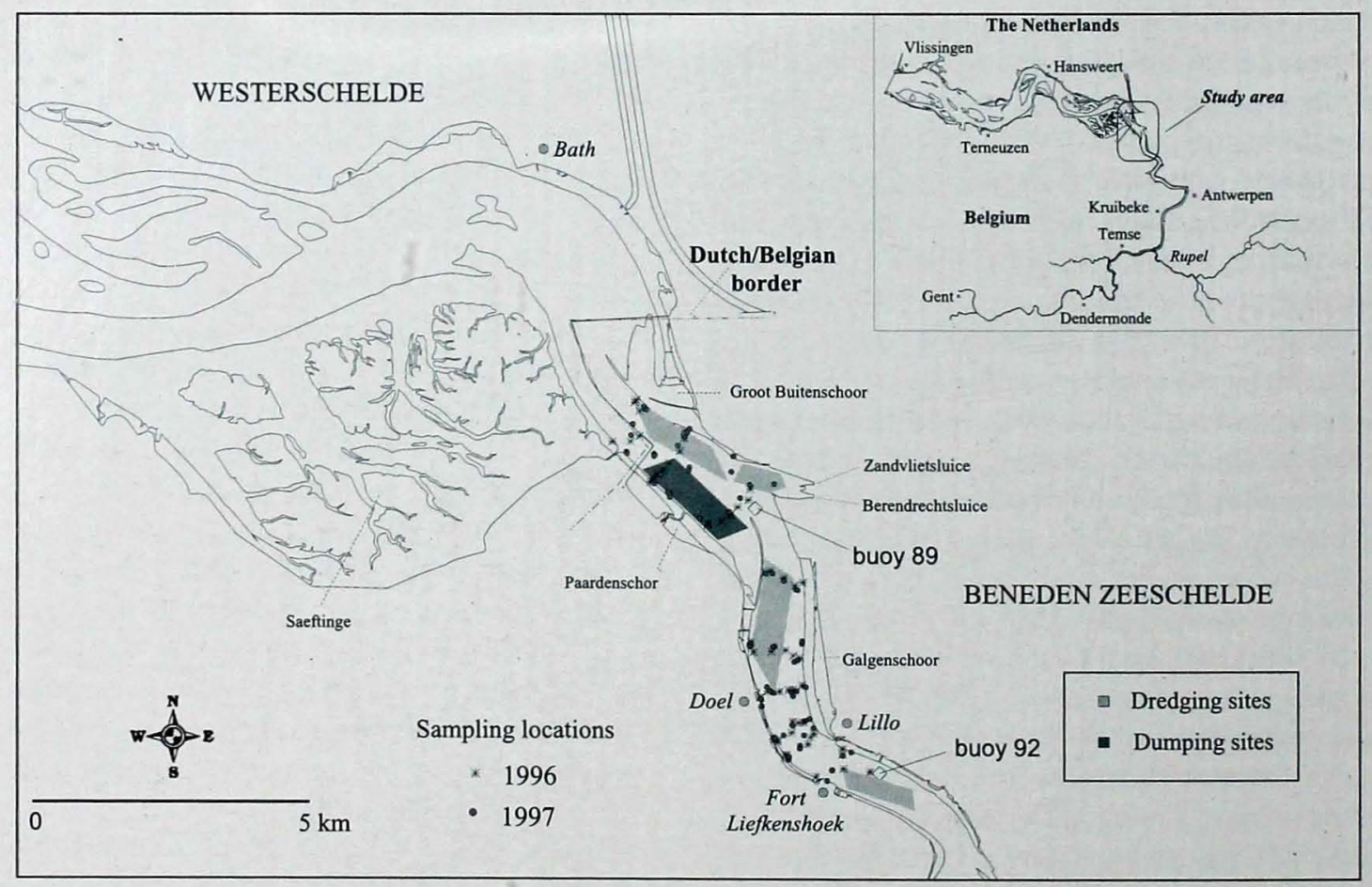

Figure 7.1. Geographical view of the Beneden Zeeschelde area with indication of the 54 and 73 sampling locations in 1996 and 1997, and with the main dredging and dumping sites in this part of the estuary. 
face deposit feeding opportunistic species. This is probably a combined effect of both natural physical and humaninduced disturbance. Only sediments with hard substrates (e.g. rocks) seem to favour species richness, providing a shelter against physical disturbance.

\section{Introduction}

The inner and upper parts of estuaries are often severely impacted by man. Land reclamation results in a high degree of estuarine habitat loss. Drainage of wastewater, dredging for shipping, safety constructions (e.g. dykes, storm surge barriers), fixation of banks, etc. change the chemical and physical properties of these estuarine habitats (COSTANZA et al. 1993; GrAY 1997).

The Schelde estuary is one of the larger NWEuropean estuaries with a complete salinity gradient, including a large freshwater tidal area. Especially the part between the Dutch-Belgian border and the Rupel is severely impacted and heavily polluted by domestic, industrial and agricultural waste loads and the concentrations of micropollutants are high (VAN ECK \& DE ROOIJ 1993; SOETAERT \& HERMAN 1995a,b; ZWOLSMAN 1999). From the 1980 's on water quality has started to improve slowly, and this improvement continues in the 1990's (VAN DAMME et al. 1995; VAN ECK et al. 1998). Near the Dutch-Belgian border, the large industrialized area of the harbour of Antwerpen is situated. Being a major sedimentation area, this zone is dredged intensively in order te keep it accessible for navigation (CLAESSENS et al. 1991). The last decade several harbour infrastructures (e.g. container terminals) have been constructed in the area, and a further deepening of the shipping channel has been undertaken.

Although the intertidal macrobenthic communities along the Schelde estuary are well known (e.g. YSEBAERT et al. 1993, 1998a), recent data about the. spatial distribution of macrobenthos in the mesohaline subtidal part of the Zeeschelde were lacking almost completely thus far. However, knowledge of the present status of the macrobenthos in this part of the estuary could give an indication of the present ecosystem health, since benthos is recognized as a suitable ecological group for monitoring and detecting effects of stress and pollution (e.g. PEARSON \& ROSENBERG 1978; BOESCH \& ROSENBERG 1981; WARWICK \& CLARK 1993; DIAZ \& ROSENBERG 1995; GASTON et al. 1998).

In this study the spatial distribution of macrobenthic communities in the mesohaline subtidal part of the Zeeschelde is described based on data collected in 1996 and 1997. The results are compared with the species diversity along the complete Schelde salinity gradient and with data from 1952 (LELOUP \& KONIETZKO 1956). Possible effects on benthic communities of dredging operations and other anthropogenic influences, like the occurrence of hard substrates within the sediment are discussed.

\section{Materials and methods}

\section{Study area}

The Schelde estuary, a macrotidal coastal plain estuary, is situated near the border between The Netherlands and Belgium. It measures $160 \mathrm{~km}$ with a surface area of approximately $350 \mathrm{~km}^{2}$. The Westerschelde $(55 \mathrm{~km})$ represents the downstream Dutch part with the polyImesohaline zone of the estuary; the Zeeschelde $(105 \mathrm{~km})$, the Belgian part of the Schelde estuary, represents the meso-/oligohaline and freshwater tidal zones (Figure 7.1). The mean tidal range is $3.8 \mathrm{~m}$ in Vlissingen, $5.2 \mathrm{~m}$ in Antwerpen and $2.0 \mathrm{~m}$ in Gent.

The study area is situated in the maximum turbidity and mesohaline zone of the Zeeschelde (BAEYENS et al. 1998; FETTWEIS et al. 1998), between the Dutch-Belgian border and Fort Liefkenshoek (Figure 7.1). In this part of the estuary mean tidal range is about $4.94 \mathrm{~m}$.

\section{Sampling and laboratory analysis}

Temperature, salinity and oxygen concentrations were measured monthly at iwo buoys in the study area (Figure 7.1). The macrobenthos was sampled in October 1996 and October 1997 in respectively 9 and 10 transects (Figure 7.1). In every transect about 6-7 locations were sampled, divided over three depth strata $(<2.95 \mathrm{~m} ; 2.95$ $7.95 \mathrm{~m} ;>7.95 \mathrm{~m}$ below MLLWS). In total 54 and 73 locations were sampled in 1996 and 1997. On each location one Van Veen grab $\left(0.105 \mathrm{~m}^{2}\right)$ was taken, from which one small core $(\varnothing 2 \mathrm{~cm})$ for sediment analysis was taken. The benthic samples were sieved through a I $\mathrm{mm}$ mesh in the field and preserved in neutralized formalin. Position and water depth of the grab sample were noted.

In the laboratory samples were sorted after staining with $0.02 \%$ Rose Bengal. All organisms were identified to species level, except for the genus Ostrea, the Oligochaeta and one Spionid specimen, and counted. The ash-free dry weight (AFDW) biomass was obtained by drying all specimens at $105^{\circ} \mathrm{C}$ for $12 \mathrm{~h}$ and ashing them at $550^{\circ} \mathrm{C}$

Sediment characteristics (median grain size, mud content (volume $\%<63 \mu \mathrm{m}$ ) were determined by laser diffraction with a Malvern Mastersizer S. Six sediment types were distinguished, according to KRAMER et al. (1994). Sediment samples containing hard substrates (e.g. stones) were all classified as type 7. Maximum ebb and flood current velocities were estimated for an average tide with the hydrodynamical model SCALDIS (VAN DER MEULEN \& SILEON 1997), having a spatial resolution of $100 \mathrm{~m}$.

\section{Data analysis}

Macrobenthic species were classified into trophic groups based on the food source: sub-surface deposit feeders (SSDF), surface deposit feeders (SDF), suspension feeders 

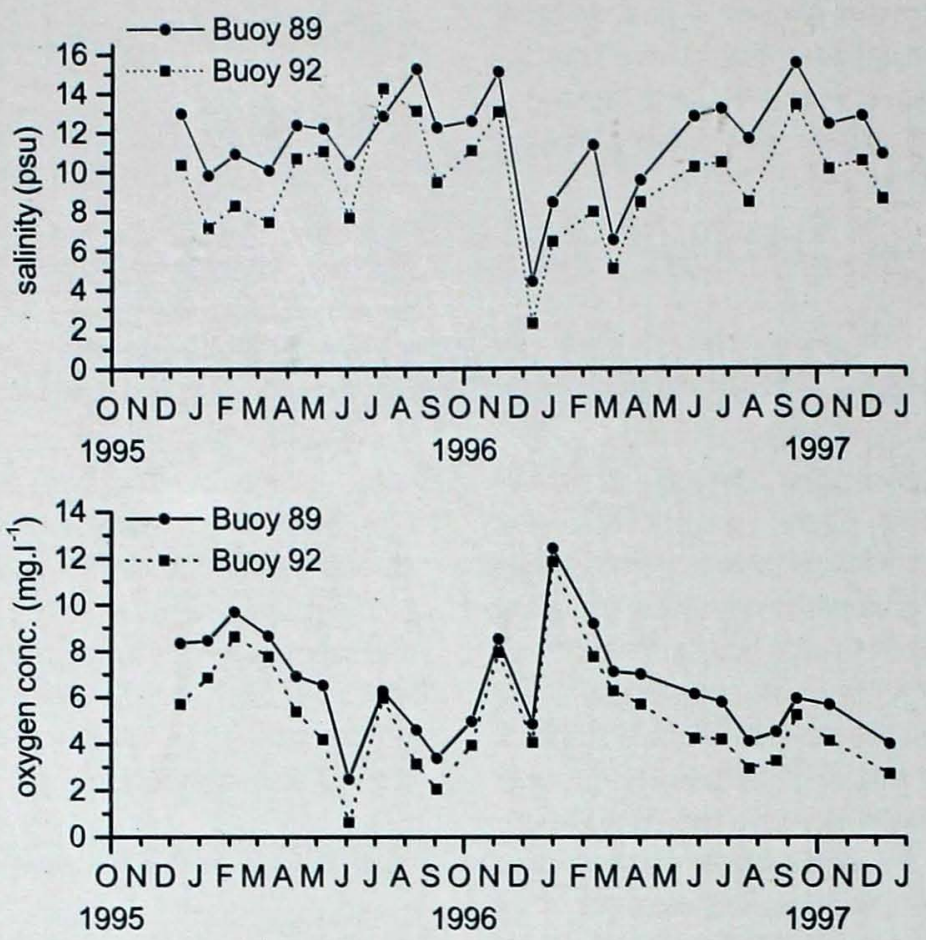

Figure 7.2. Monthly measurements of salinity and oxygen concentrations at buoy 89 and 92 within the study area (for geographic positions of the buoys, see Figure 1).

(SF), omnivores (O) and predators (P). Spionid species and Macoma balthica (Linnaeus) were classified as SDF-SF, as these species may switch between both feeding types.

The abundance/biomass comparison method - ABC ( $k$-dominance curves for species abundance and biomass (LAMBSHEAD et al. 1983) was used to detect environmental stress (WARWick 1986; Meire \& DeReu 1990).

To identify groups of similar locations the following analyses were performed on the density datasets of 1996, 1997 and 1996-1997 together (fourth root transformed): a classification (clustering.based on the Bray-Curtis similarity index and Group Average Sorting - GAS) (CLIFFORD \& STEPHENSON 1975), an ordination (Multi Dimensional Scaling - MDS) (KRUSKAL \& WISH 1978), and a hybrid technique (Two-Way Indicator Species Analysis - TwINSPAN) (HILL 1979). Cut-levels used were 0, 2.0, 2.3, 2.7. 3.5, 4.5. Rare species (single observation), the epibenthic shrimps Crangon crangon (Linnaeus) and Palaemon longirostris (Milne Edwards), empty samples (3 in 1996, 5 in 1997) and samples with only one individual were excluded from the analyses. The relationship between the spatial distribution of the locations in the MDS ordination and the environmental variables was indicated by a Spearman Rank Order Correlation between the axes from the ordination and the environmental variables. The clusters, resulting from the multivariate analyses, were characterized by their typical species composition, diversity (Shannon Wiener diversity index $\mathrm{H}^{\prime}$ ) and the environmental variables. Statistical differences for biotic and abiotic variables among groups were analysed by KruskalWallis test. Mean values are given with standard error (SE).

\section{Results}

\section{Abiotic characterization of the sampling locations}

Water quality measurements at the two buoys in the study area (Figure 7.I) showed a strong seasonal pattern in water temperature and smaller seasonal fluctuations in salinity and oxygen concentrations, which were related to the river runoff, being higher in winter (Figure 7.2). The area was mesohaline (yearly average 1996: 10.5 psu; 1997: $10.1 \mathrm{psu}$ ) throughout the year (one exception in December 1996). Oxygen concentrations were often less than $5 \mathrm{mg} \mathrm{O}^{2} \mathrm{H}^{-1}$, especially in summer.

Mean median grain size and mean mud content were $141 \pm 19 \mu \mathrm{m}$ and $38 \pm 4 \%$ respectively, both showing a large variation. In both years the dominant sediment type was silt (Table 7.1). 5.5\% in 1996 and 12\% in 1997 belonged to the sediment types medium sand (250-500 $\mu \mathrm{m})$ and coarse sand (500-1000 $\mu \mathrm{m})$, hereafter considered together as the sediment type medium-coarse sand. 13\% in 1996 and $20.5 \%$ in 1997 of the samples were of sediments with hard substrates. Mud fraction slightly decreased and median grain size slightly increased with depth, but there was no significant correlation with depth (median grain size: Spearman $R=0.18 ; P=0.06$ and mud fraction: Spearman $R=-0.17 ; P=0.08 ; N=86$ ).

Based on model calculations, mean maximum ebb and flood current velocities were $0.886 \pm 0.06 \mathrm{~m} \mathrm{~s}^{-1}$ and 0.786 
Table 7.1. Sediment types, based on median grain size, of the subtidal sampling locations in 1996 ( $N=54)$ and 1997 ( $N=73)$ respectively.

\begin{tabular}{llccccc}
\hline \multicolumn{2}{l}{ Sediment type } & Range $(\boldsymbol{\mu m})$ & \multicolumn{2}{c}{1996} & \multicolumn{2}{c}{1997} \\
\multicolumn{1}{l}{} & & \# samples & $\%$ & \# samples & $\%$ \\
\hline type I clay & $<2$ & 0 & 0.0 & 0 & 0.0 \\
type 2 silt & $2-63$ & 18 & 33.3 & 24 & 32.9 \\
type 3 & very fine sand & $63-125$ & 9 & 16.7 & 9 & 12.3 \\
type 4 & fine sand & $125-250$ & 17 & 31.5 & 16 & 21.9 \\
type 5 & medium sand & $250-500$ & 3 & 5.5 & 7 & 9.6 \\
type 6 & coarse sand & $500-1000$ & 0 & 0.0 & 2 & 2.7 \\
type 7 & hard substrate & -- & 7 & 13.0 & 15 & 20.5 \\
\hline
\end{tabular}

$\pm 0.020 \mathrm{~m} \mathrm{~s}^{-1}(\mathrm{~N}=127)$ respectively. Only at three locations the model calculated current velocities lower then $0.20 \mathrm{~m} \mathrm{~s}^{-1}$. Highest current velocities observed were 1.23 and $1.16 \mathrm{~m} \mathrm{~s}^{-1}$ under ebb and flood condititions respectively. No correlation was found between current velocitiess and depth $(N=127$; Spearman $R=0.13 ; P=0.16)$, nor between current velocities and median grain size $(N=106$; Spearman $R=0.13 ; P=0.20)$ or mud content $(N=106$; Spearman $R=-0.12 ; P=0.22$ ).

\section{General characteristics of the macroben- thic fauna}

Of the 35 species observed ( 28 in 1996; 24 in 1997), $31 \%$ were annelids, $26 \%$ molluscs and $43 \%$ arthropods (Table 7.2). Only seven species occurred in more than $20 \%$ of the samples. The polychaete Heteromastus filiformis (Claparède). (65\% of the samples in 1996, 33\% in 1997) and Oligochaeta $(61.5 \%$ in 1996, 50.7\% in 1997) were most common. Six species were observed only once. The number of species per location was low (Figure 7.3); locations with one or two species were most common (44\%).

The mean total density of all locations was $681 \pm 171$ ind $\mathrm{m}^{-2}$, the mean density in $1996\left(861 \pm 341\right.$ ind $\left.\mathrm{m}^{-2}\right)$ was noticeable higher than in 1997 (549 \pm 158 ind $\mathrm{m}^{-2}$ ), although not significantly (Mann-Whitney U-test: $\mathrm{N}(1996)=54$; $N(1997)=73 ; U=1720 ; P=0.2227)$. Densities were dominated by annelids ( $87 \%$ of the total density; $89 \%$ in 1996; $84 \%$ in 1997) (Table 7.2). Arthropods occurred to a lesser extent and molluscs occurred only in very low densities (Figure 7.4). Most locations had a total density between $100-1000$ ind $\mathrm{m}^{-2}$ in $1996(42 \%)$ and between $10-100$ ind $\mathrm{m}^{-2}$ in 1997 (44\%) (Figure 7.3). Highest densities observed were 17352 and 9286 ind $\mathrm{m}^{-2}$ in 1996 and 1997 respectively.

The mean total biomass of all locations was $0.94 \pm$ $0.35 \mathrm{~g} \mathrm{AFDW} \mathrm{m}^{-2}$. In 1996 mean biomass $(1.26 \pm 0.75 \mathrm{~g}$ AFDW m $\left.\mathrm{m}^{-2}\right)$ was higher than in $1997(0.68 \pm 0.24 \mathrm{gAFDW}$ $\mathrm{m}^{-2}$ ), although not significantly (Mann-Whitney U-test: $N(1996)=54 ; N(1997)=73 ; U=1911.5 ; P=0.77)$. The difference in biomass was caused by the high biomass of a few oysters (Crassostrea angulata (Lamarck) and Ostrea spp. found at 3 and 2 sampling locations in 1996 and 1997 respectively, and making $67 \%$ of total biomass in 1996 and only $20 \%$ of total biomass in 1997 . If oysters were removed from the dataset, mean biomass of both years was more comparable (1996: 0.41 $\pm 0.13 \mathrm{~g}$ AFDW $\mathrm{m}^{-2}$ 1997: $0.55 \pm 0.16 \mathrm{~g} \mathrm{AFDW} \mathrm{m}^{-2}$ ). Contrary to density, biomass was not only dominated by annelids (1996: 50\%; 1997 30\%), but also by arthropods (1996: 42\%; 1997: 66\%) (Figure 7.4). The dominant annelids were Polydora ligerica (Ferronière) and $\mathrm{H}$. filiformis; the dominant arthropods were Crangon crangon and Palaemon longirostris (Table 7.2). It should be emphasized that these arthropods were all epibenthic species, and therefore do not belong to the sedentary infauna. Most locations (55\%) had a total biomass between 0.01-1 $\mathrm{g}$ AFDW $\mathrm{m}^{-2}$ (Figure 7.3), with a maximum of $40 \mathrm{~g}$ AFDW m-2 (a location with 12 oysters) in 1996 and $15 \mathrm{~g} \mathrm{AFDW} \mathrm{m}^{-2}$ in 1997.

The macrobenthic community was numerically dominated by SDF-SF species (59\%), which were mainly the spionids Polydora ligerica and Polydora ligni (Webster). The other important group were SSDF with $29 \%$, being represented by $\mathrm{H}$. filiformis and Oligochaeta. Suspension feeders (oysters) dominated the biomass (47\%), but when these few oysters were excluded predators dominated (55\%), followed by SDF-SF (spionids) with 20\%. The predators were mainly the epibenthic shrimps $C$. crangon and P. longirostris, not being a permanent part of the benthic infauna.

The-k-dominance curves for species abundance and biomass (besides oysters) ( $A B C$-curves) showed a stressed pattern, as indicated by the abundance curve falling above the biomass curve (Figure 7.5). This means that the benthic community was dominated by one or a few very small species and only a few larger species were present.

\section{Community structure and environmental variables}

The multivariate analyses did not produce a distinction between the datasets of 1996 and 1997. Therefore the 
Table 7.2. Number of observations (\%), mean density (ind $m^{-2}$ ) and mean biomass ( $g$ AFDW $m^{-2}$ ) of all macrobenthic species observed in the subtidal, mesohaline zone of the Zeeschelde estuary in $1996(N=54)$ and $1997(N=73)$ respectively.

\begin{tabular}{|c|c|c|c|c|c|c|}
\hline & \multicolumn{3}{|c|}{1996} & \multicolumn{3}{|c|}{1997} \\
\hline & $\begin{array}{c}\text { \# observations } \\
\%\end{array}$ & $\begin{array}{l}\text { Density } \\
\text { ind } \mathrm{m}^{-2} \\
\end{array}$ & $\begin{array}{c}\text { Biomass } \\
\text { g AFDW m-2 }\end{array}$ & $\begin{array}{c}\text { \# observations } \\
\%\end{array}$ & $\begin{array}{l}\text { Density } \\
\text { ind } \mathrm{m}^{-2} \\
\end{array}$ & $\begin{array}{c}\text { Biomass } \\
\text { g AFDW m-2 }\end{array}$ \\
\hline \multicolumn{7}{|l|}{ Annelida } \\
\hline Eteone longa $(\mathrm{P})$ & 5.5 & 0.9 & 0.0004 & * & * & * \\
\hline Harmothoe impar $(\mathrm{P})$ & 3.6 & 0.4 & 0.0004 & 1.4 & 0.1 & $0.000 !$ \\
\hline Heteromastus filiformis (DF) & 65.5 & 143.4 & 0.0575 & 32.9 & 74.4 & 0.0642 \\
\hline Marenzelleria spp. (P) & 1.8 & 0.4 & - & 1.4 & 0.3 & * \\
\hline Nereis diversicolor $(\mathrm{O})$ & * & * & * & $1.4^{2}$ & 0.1 & 0.0001 \\
\hline Nereis succinea (DF) & 25.5 & 23.0 & 0.0492 & 26.0 & 22.2 & 0.0403 \\
\hline Oligochaeta (DF) & 61.5 & 58.2 & 0.0015 & 50.7 & 72.3 & 0.0014 \\
\hline Polydora ligerica (SDF-SF) & 34.5 & 479.6 & 0.0908 & 27.4 & 232.0 & 0.050 .1 \\
\hline Polydora ligni (SDF-SF) & 23.6 & 47.0 & 0.0085 & 27.4 & 55.3 & 0.0077 \\
\hline Pygospio elegans (SDF-SF) & 16.4 & 4.2 & 0.0002 & 15.0 & 6.0 & 0.0016 \\
\hline Spionidae spp. (SDF-SF) & 1.8 & 0.2 & - & * & * & * \\
\hline \multicolumn{7}{|l|}{ Molllusca } \\
\hline Barnea candida (SF) & 1.8 & 0.4 & 0.0040 & * & * & * \\
\hline Cerastoderma edule (SF) & 1.8 & 0.2 & 0.0004 & * & * & * \\
\hline Crassostrea angulata (SF) & 5.5 & 2.4 & 0.8432 & * & * & * \\
\hline Hydrobia ulvae (SDF) & 3.6 & 0.4 & 0.0001 & * & * & * \\
\hline Macoma balthica (SDF-SF) & 16.4 & 2.9 & 0.0267 & 16.4 & 3.3 & 0.0206 \\
\hline Mya arenaria (SF) & 9.1 & 2.1 & 0.0037 & 4.1 & 1.2 & 0.0004 \\
\hline Mytilus edulis (SF) & 7.3 & 1.0 & 0.0002 & 2.7 & 0.4 & 0.0006 \\
\hline Ostrea spp. (SF) & * & * & * & 2.7 & 0.4 & 0.1337 \\
\hline Petricola pholadiformis (SF) & * & * & 0.0004 & 1.4 & 0.4 & - \\
\hline \multicolumn{7}{|l|}{ Arthropoda } \\
\hline Bathyporeia elegans (SDF) & 7.3 & 0.9 & 0.0002 & 1.4 & 0.1 & 0.0000 \\
\hline Bathyporeia pilosa (SDF) & 31.0 & 23.4 & 0.0023 & 22.0 & 5.9 & 0.0004 \\
\hline Corophium insidiosum (SDF) & 11.0 & 8.3 & 0.0005 & 13.7 & 5.7 & 0.0002 \\
\hline Corophium lacustre (SDF) & 14.5 & 15.2 & 0.0019 & 13.7 & 16.2 & 0.0016 \\
\hline Corophium volutator (SDF) & 23.6 & 23.7 & 0.0049 & 32.9 & 38.4 & 0.0055 \\
\hline Crangon crangon (P) & 14.5 & 1.4 & 0.0517 & 15.1 & 1.8 & 0.1755 \\
\hline Eurydice pulchra (P) & 9.1 & 1.9 & 0.0015 & 9.6 & 1.0 & 0.0022 \\
\hline Gammarus salinus (O) & 1.8 & 0.2 & 0.0003 & 4.1 & 1.3 & 0.0011 \\
\hline Melita palmata (SDF) & 1.8 & 0.2 & 0.0004 & 1.4 & 0.3 & 0.0006 \\
\hline Mesopodopsis slabberii $(\mathrm{O})$ & 3.6 & 0.4 & 0.0001 & 5.5 & 0.7 & 0.0000 \\
\hline Neomysis integer $(\mathrm{O})$ & 1.8 & 0.2 & - & * & * & * \\
\hline Palaemon longirostris $(\mathrm{P})$ & 3.6 & 0.5 & 0.0845 & 9.6 & 1.0 & 0.1241 \\
\hline Pleusymtes glaber (SDF) & 12.7 & 4.8 & 0.0008 & 15.1 & 8.7 & 0.0011 \\
\hline Rhithropanopeus harrisii (P) & 3.6 & 0.5 & 0.0186 & 9.6 & 1.3 & 0.0481 \\
\hline Balanus spp. (SF) & Present & & & present & & \\
\hline
\end{tabular}

*, not found; -, not determined

further analysis and discussion of community structure is based on the data of both years together. Both Twinspan and Cluster analyses produced three clusters, which also returned in the MDS ordination (Figure 7:6A). In the GASclassification the first cluster (cluster I) was separated at a $15 \%$ similarity, the two remaining at a $35 \%$ similarity. 16 locations mutually showed very little similarity and did not form a cluster. These locations were considered as group 4 (restgroup).
Neither macrobenthos species richness, density, biomass, nor one of the MDS-axes were significantly correlated with depth (Table 7.3). On the other hand, mud content was significantly correlated with macrobenthos species richness and density, being highest for the silt type sediment. Both axes of the MDS ordination were significantly correlated with mud content and median grain size, indicating that the distribution of the samples in the MDS ordination was mainly determined by the sediment parame- 

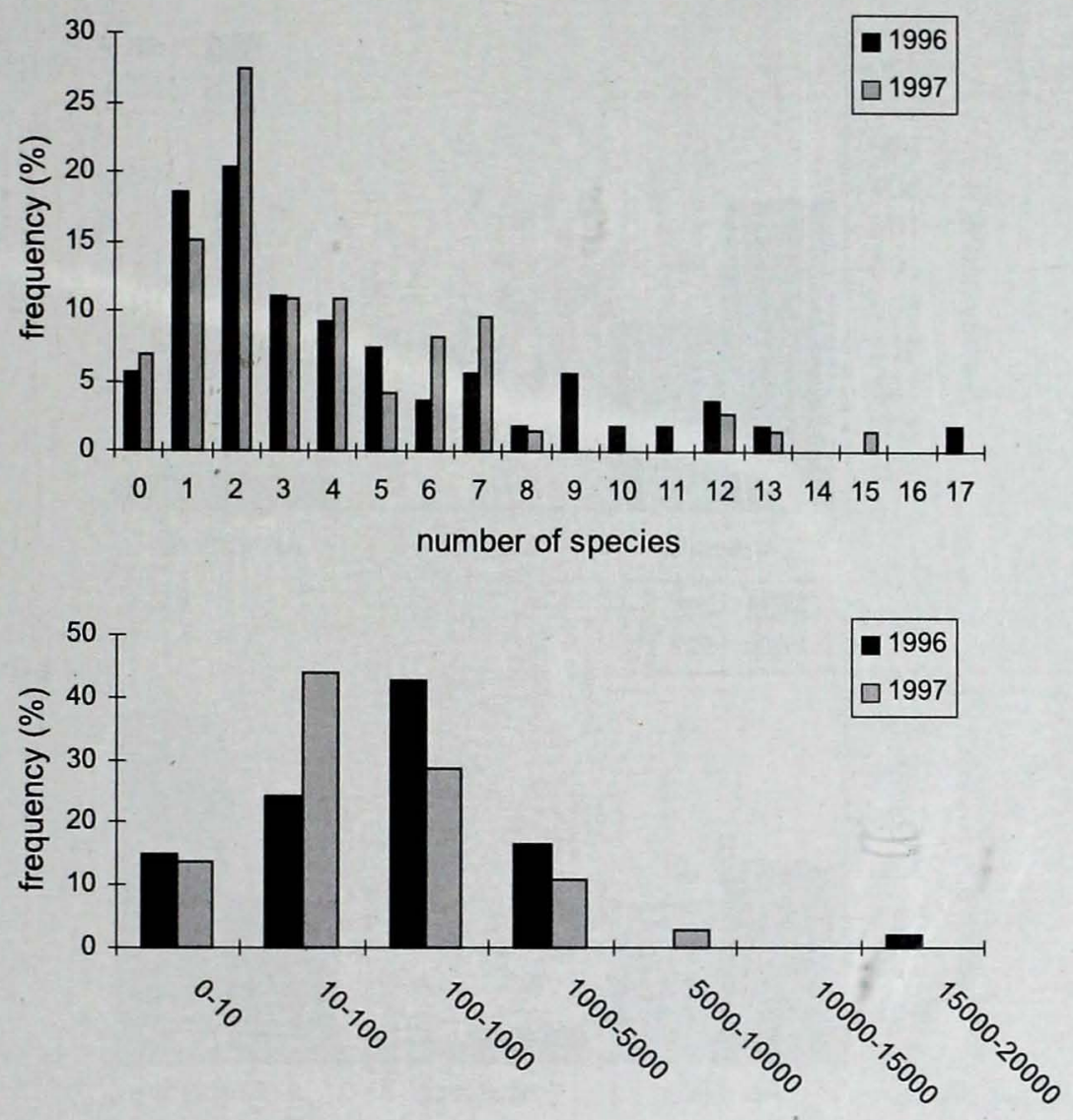

density (ind $\mathrm{m}^{-2}$ )

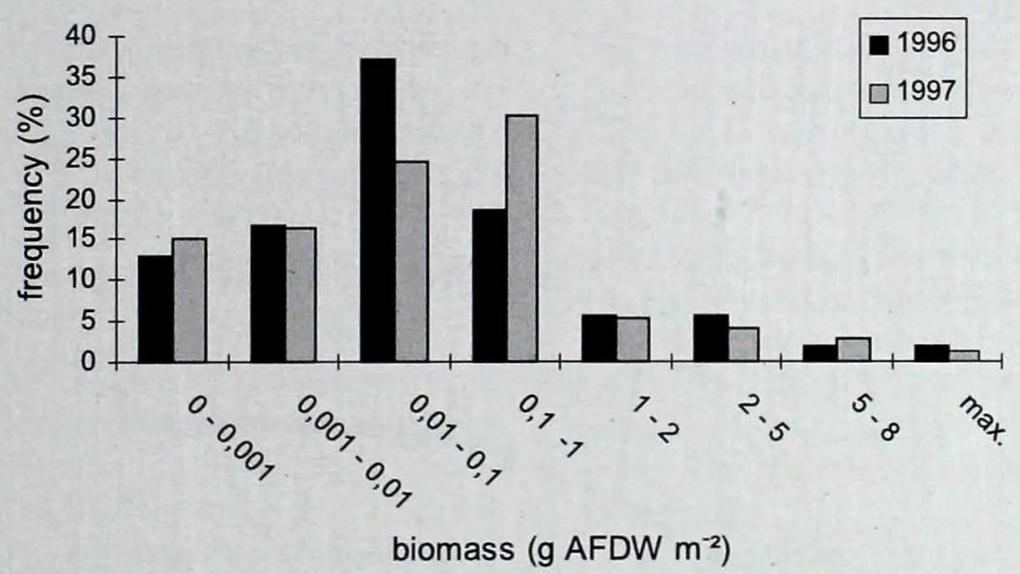

Figure 7.3. Species distribution (\%), density distribution (\%) and biomass distribution (\%) of the 54 and 73 sampling locations in 1996 and 1997 respectively.

ters. The superimposed sediment types on the ordination (Figure 7.6B) showed a clear tendency of grouping. Cluster I mostly occurred on fine sand sediment (70\%), cluster 2 on silt (34\%) and hard substrate (34\%) sediments, and cluster 3 mainly on silt (58\%) - very fine sand (39\%) sediments.

The ABC-curves for each cluster separately showed a similar stressed pattern as observed for all sampling locations together (see Figure 7.5). The abiotic and biotic characteristics of the three clusters and the statistical difference among the clusters are summarized in Table 7.4. Cluster
I was characterized by a species-poor benthic fauna with a typical dominance of the amphipod Bathyporeia pilosa (Lindström) (Figure 7.7A, 7.8A). Cluster 2 consisted of locations with a relatively species-rich benthic fauna with a high mean density and biomass. The small polychaete Polydora ligerica was the indicator species (Figure 7.7B, $7.8 \mathrm{~B})$. Oysters occurred exclusively in this cluster, explaining the relatively high biomass. Cluster 3 was characterized by intermediate species richness, density and biomass. The indicator species of this cluster were Heteromastus fliformis 


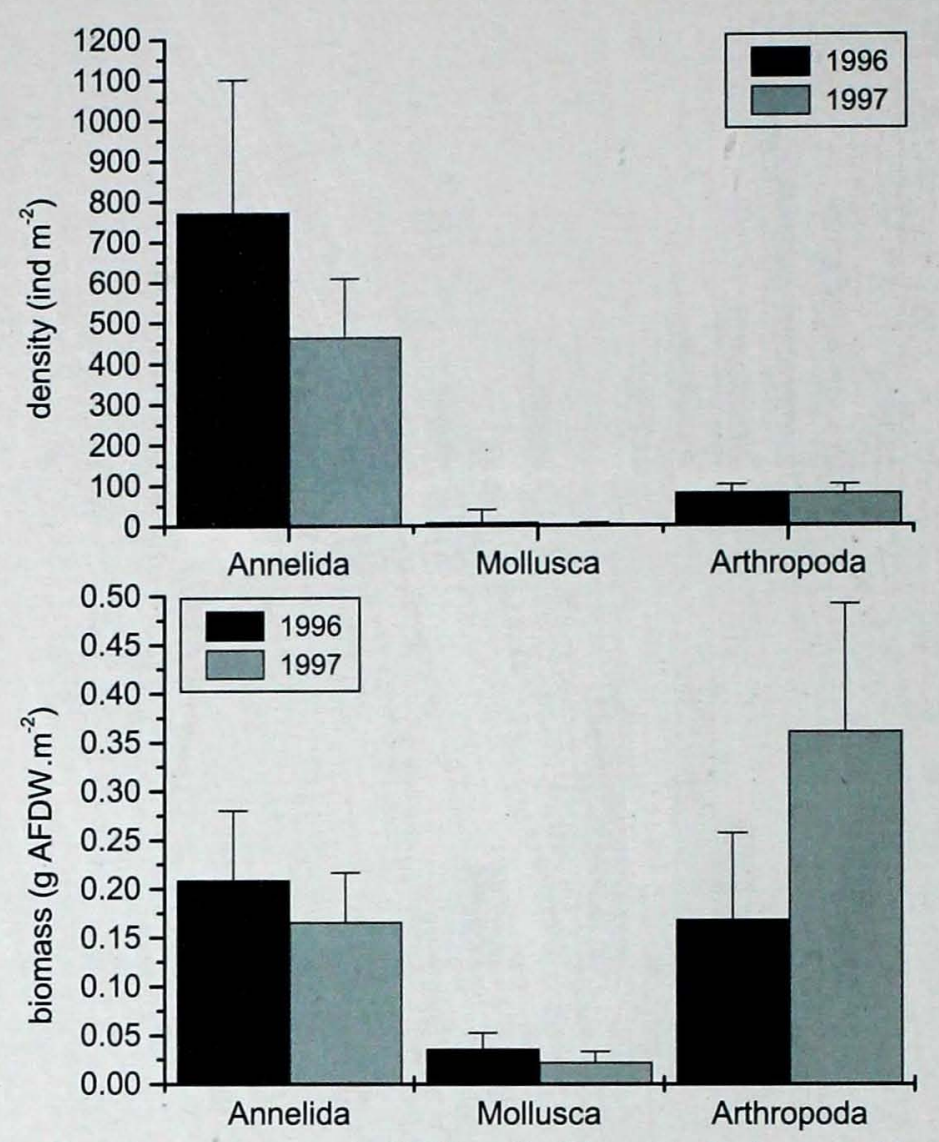

Figure 7.4. Mean density (ind $\mathrm{m}^{-2}$ ) and mean biomass ( $\mathrm{g}$ AFDW m-2) of Annelida, Mollusca and Arthropoda in 1996 and 1997. The biomass of oysters is not included in the mean total biomass of the Mollusca.

and Oligochaeta (Figure 7.7C,D and 7.8C). Macoma balthica, only present in low densities, appeared almost exclusively in cluster 3. Sediment characteristics were significantly different among the three clusters, depth was not significantly different.

Of group 4, 37\% of the locations were situated in the silt sediment type, $30 \%$ on hard substrates, and the remain- ing locations in the other sediment types. Generally the samples contained few species in low densities. Characteristically $57 \%$ of the locations of group 4 were found in the depth stratum $>7.5 \mathrm{~m}$, with a mean depth of $9.5 \pm 1.4 \mathrm{~m}$, which was noticeably deeper than the mean depth of the three clusters.

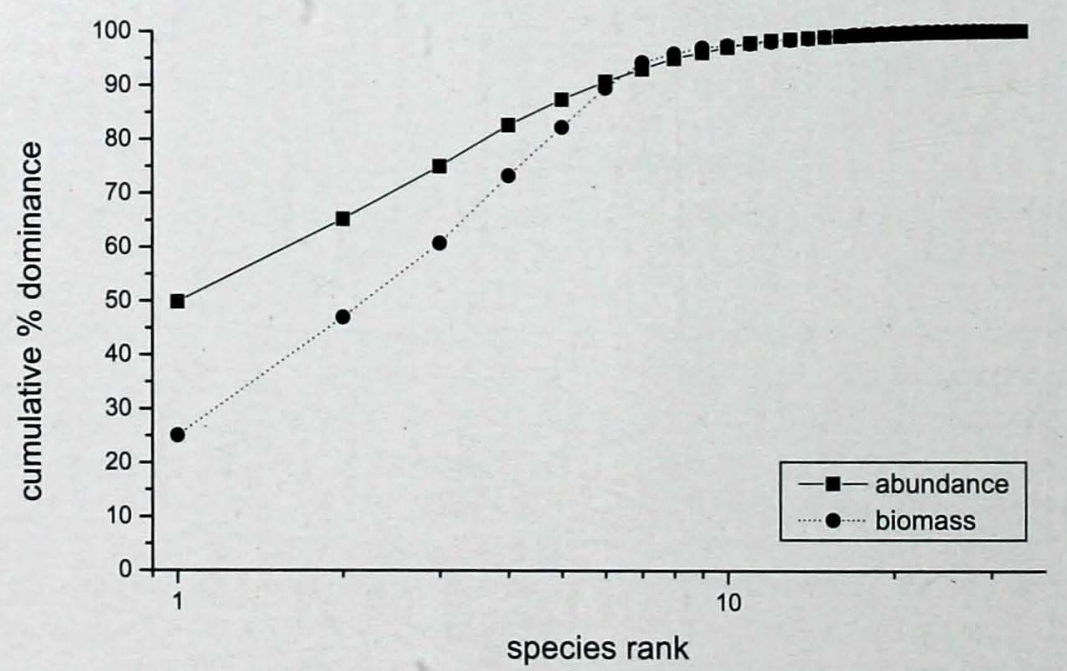

Figure 7.5. Combined k-dominance curves for species abundance and biomass ( $A B C$-curve), based on all sampling locations (1996 and 1997 together). 


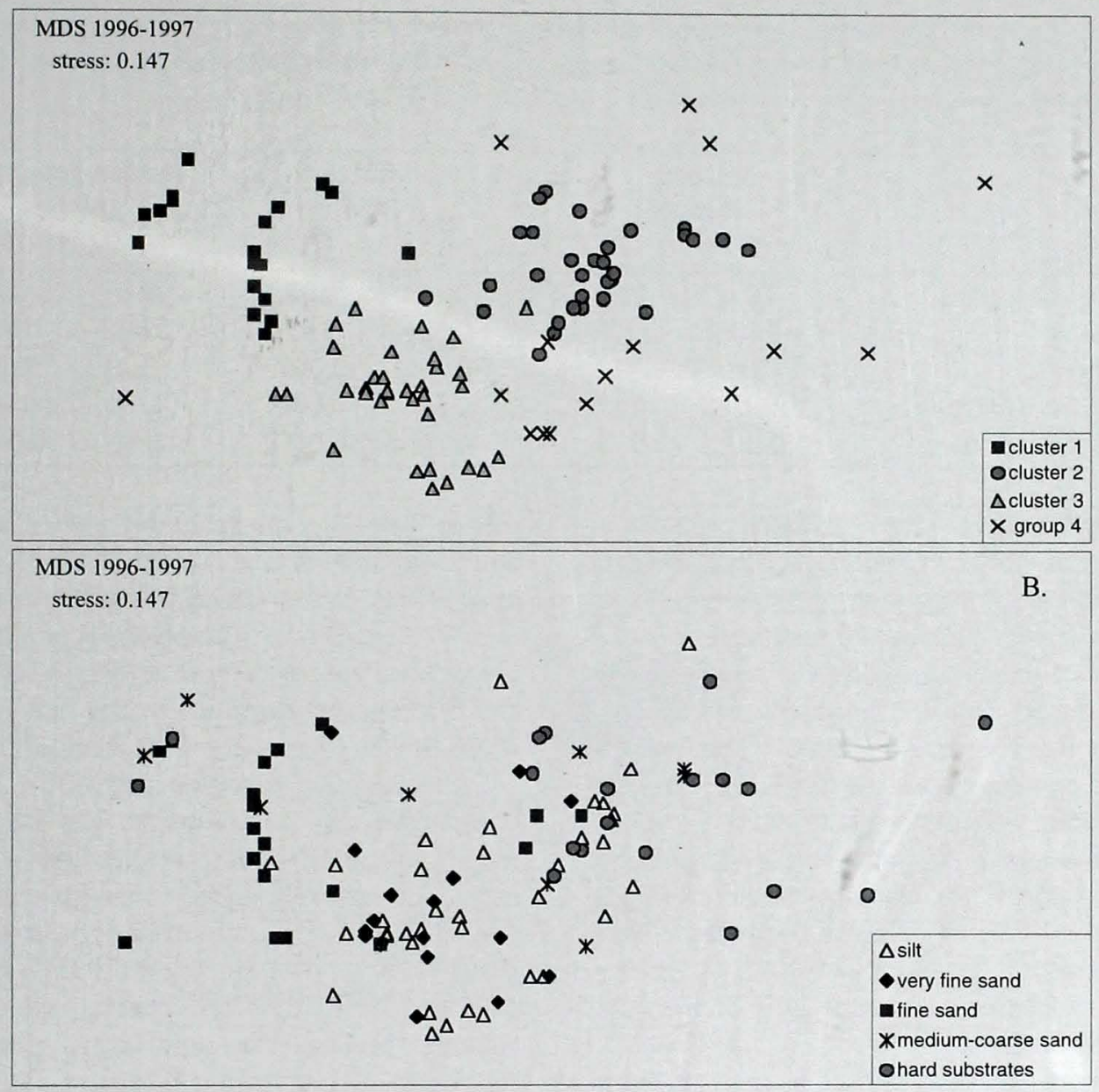

Figure 7.6. MDS ordination of species density data from 1996 and 1997 together. A. Clusters superimposed on the ordination. B. Sediment types superimposed on the ordination.

\section{Discussion}

\section{Species diversity along the salinity gradient in the Schelde estuary}

The most important variables controlling the occurrence of benthic organisms on an estuarine scale are salinity and sediment characteristics (e.g. WOLFF 1973; BOESCH 1977; HOLLAND et al. 1987; RAKOCINSKI et al. 1997; YSEBAERT et al. 1998a), which are in turn determined largely by hydrodynamic conditions (e.g. WILDISH \& KRISTMANSON 1979; WARWICK \& UNCLES 1980; WARWICK et al. 1991; HALL 1994). It is assumed that the environmental stress, due to salinity and hydrodynamic conditions, is greatest in the subtidal part of the middle and upper regions of estuaries, resulting in a lower diversity of benthic invertebrates predicted in these areas. The aim of this study was to investigate the macrobenthic community of the subtidal mesohaline part of the Zeeschelde estuary.

SEYS et al. (1999b) recently investigated the benthos of the Zeeschelde, but this study concentrated on Oligochaeta, and therefore was based on only one small sediment core per sampling location (diameter $3.5 \mathrm{~cm}$ ). Only a few locations were situated within the subtidal mesohaline part of the Zeeschelde estuary. Apart from two Oligochaeta species found (Heterochaeta costata (Claparède) and Tubificoides heterochaetus (Michaelsen)), only four macrobenthic species were determined in these locations: Polydora ligerica, Heteromastus filiformis, Nereis succinea (Frey \& Leuckart) and Macoma balthica. The different sampling method and the small amount of locations may explain the large difference in species number as compared to this study.

The subtidal part of the Westerschelde was recently studied as part of a monitoring programme (e.g. BRUMmelhuis et al. 1997; Craeymeersch 1999). For the same period (autumn 1996-1997), 55 macrobenthic species were observed. Species diversity decreased from the polyhaline zone ( 40 species, 30 sampling locations each year), over the poly-/mesohaline transition zone (31 species, idem) to the $\alpha$-mesohaline zone ( 27 species, idem). In this study no further decrease in the number of species was observed in the $\beta$-mesohaline part of the estuary. Instead, species diversity slightly increased (35 species). The presence of sediments with hard substrates, often having a high macrobenthic species richness, may account for this. Also, the sampling effort in this study was larger as com- 
Table 7.3. Spearman Rank Order Correlations between environmental factors (depth, mud content, median grain size) and the number of species, biomass, density, and MDS $X$-and $Y$-co-ordinates. The Spearman $R$ and the $P$-value are given. Significant correlations at the level $P<0,05$ are in bold.

\begin{tabular}{|c|c|c|c|c|c|c|}
\hline & \multicolumn{2}{|c|}{$\begin{array}{l}\text { Depth } \\
(N=105)\end{array}$} & \multicolumn{2}{|c|}{$\begin{array}{l}\text { mud fraction } \\
\qquad(\mathrm{N}=86)\end{array}$} & \multicolumn{2}{|c|}{$\begin{array}{l}\text { median grain size } \\
\qquad(\mathrm{N}=86)\end{array}$} \\
\hline & $R$ & $P$ & R & $P$ & $R$ & $P$ \\
\hline Number of species & $-0,052$ & 0,60 & 0,24 & 0,03 & $-0,14$ & 0,20 \\
\hline Biomass & $-0,108$ & 0,27 & 0,05 & 0,63 & 0,001 & 0,99 \\
\hline Density & 0,04 & 0,67 & 0,30 & 0,005 & $-0,20$ & 0,05 \\
\hline MDS $\times$ co-ordinates & 0,15 & 0,12 & 0,57 & $<0,0001$ & $-0,41$ & $<0,0001$ \\
\hline MDSY co-ordinates & 0,10 & 0,31 & $-0,42$ & $<0,0001$ & 0,39 & 0,0002 \\
\hline
\end{tabular}

pared to the sampling effort in the monitoring programme of the Westerschelde. When considering the available data from this study for all sampling years (1990-1997), to increase the sampling effort, about 100 taxa were found in the subtidal part of the Westerschelde. The number of species also decreased from the polyhaline (70 species) towards the mesohaline zone (50 species). Therefore, the observed species diversity was also a function of sampling effort. Many species were reported to occur irregularly and rather accidentally, with in general very few species per sampling location, and this was also observed in this study. On the other hand, species diversity 'hot spots' were sometimes observed. In this study one sampling location represented 17 macrobenthic species, half of the total number of species observed.

Species diversity was reported to be much lower in the oligohaline zone of the Zeeschelde, characterized by an impoverished benthic fauna, with a few Oligochaeta spe- cies and very few macrobenthic species, such as $P$. ligerica and Corophium volutator (Pallas) (YSEBAERT et al. 1993; SEYS et al. 1999b). In the subtidal freshwater tidal zone the community was almost completely composed of a few Oligochaeta species (SEYs et al. 1999b). This very low species diversity was explained by the heavy pollution in the oligohaline and freshwater tidal zones of the Zeeschelde.

The subtidal mesohaline part of the Zeeschelde was characterized by some typical 'genuine brackish-water' species, species which according to REMANE (1969) showed a distribution strictly limited to the mixohaline zones without expansion into the marine or freshwater regions (WOLFF 1973 ; MICHAELIS et al. 1992). In our study the observed 'brackish-water' species are the polychaete Polydora ligerica, the amphipods Gammarus salinus (Spooner), Corophium insidiosum (Crawford) and Corophium lacustre (Vanhöffen), the shrimp Palaemon longirostris and the crab Rhitropanopeus harrisii (Gould). The

Table 7.4. Biotic and abiotic characterization of the three clusters (mean \pm SE), with indication of the test statistic $(H)$ of the Kruskal-Wallis test together with the P-level for differences among the three clusters.

\begin{tabular}{|c|c|c|c|c|c|}
\hline & $\begin{array}{c}\text { Cluster I } \\
(n=23)\end{array}$ & $\begin{array}{c}\text { Cluster } 2 \\
(n=35)\end{array}$ & $\begin{array}{c}\text { Cluster } 3 \\
(n=3 \mid)\end{array}$ & $\mathrm{H}$ & P-level \\
\hline Total number of species & 9 & 22 & 12 & & \\
\hline Mean number of species & $2.3 \pm 0.25$ & $8.8 \pm 0.56$ & $2.9 \pm 0.22$ & 71.245 & $<0.0001$ \\
\hline Shannon-Wiener diversity $H^{\prime}$ & $0.53 \pm 0.079$ & $1.20 \pm 0.097$ & $0.69 \pm 0.069$ & 16.037 & 0.0003 \\
\hline Mean density (ind $\mathrm{m}^{-2}$ ) & $86 \pm 18$ & $2298 \pm 613$ & $248 \pm 76$ & 40.513 & $<0.000$ \\
\hline Mean biomass (g AFDW $\mathrm{m}^{-2}$ ) & $0.02 \pm 0.004$ & $3.07 \pm 1.343$ & $0.25 \pm 0.087$ & 44.397 & $<0.0001$ \\
\hline \multicolumn{6}{|l|}{ Indicator species (density) } \\
\hline Bathyporeia pilosa & $65 \pm 13$ & $0.6 \pm 0.43$ & $2.7 \pm 1.81$ & 68.873 & $<0.0001$ \\
\hline Polydora ligerica & $5.2 \pm 4.36$ & $|379 \pm 57|$ & 0 & 58.779 & $<0.0001$ \\
\hline Heteromastus filiformis & $2.4 \pm 0.86$ & $234 \pm 143$ & $170 \pm 70$ & 20.876 & $<0.0001$ \\
\hline Oligochaeta & $6.3 \pm 4.75$ & $168 \pm 56$ & $54 \pm 11$ & 22.275 & $<0.0001$ \\
\hline Mud content (\%) & $7.5 \pm 3.38$ & $48 \pm 5.9$ & $48 \pm 4.1$ & 22.509 & $<0.0001$ \\
\hline Median grain size $(\mu \mathrm{m})$ & $215 \pm 19$ & $|33 \pm 4|$ & $76 \pm 9$ & 22.776 & $<0.0001$ \\
\hline Depth & $6.2 \pm i .1$ & $6.3 \pm 0.8$ & $5.1 \pm 0.8$ & 0.827 & 0.661 \\
\hline
\end{tabular}



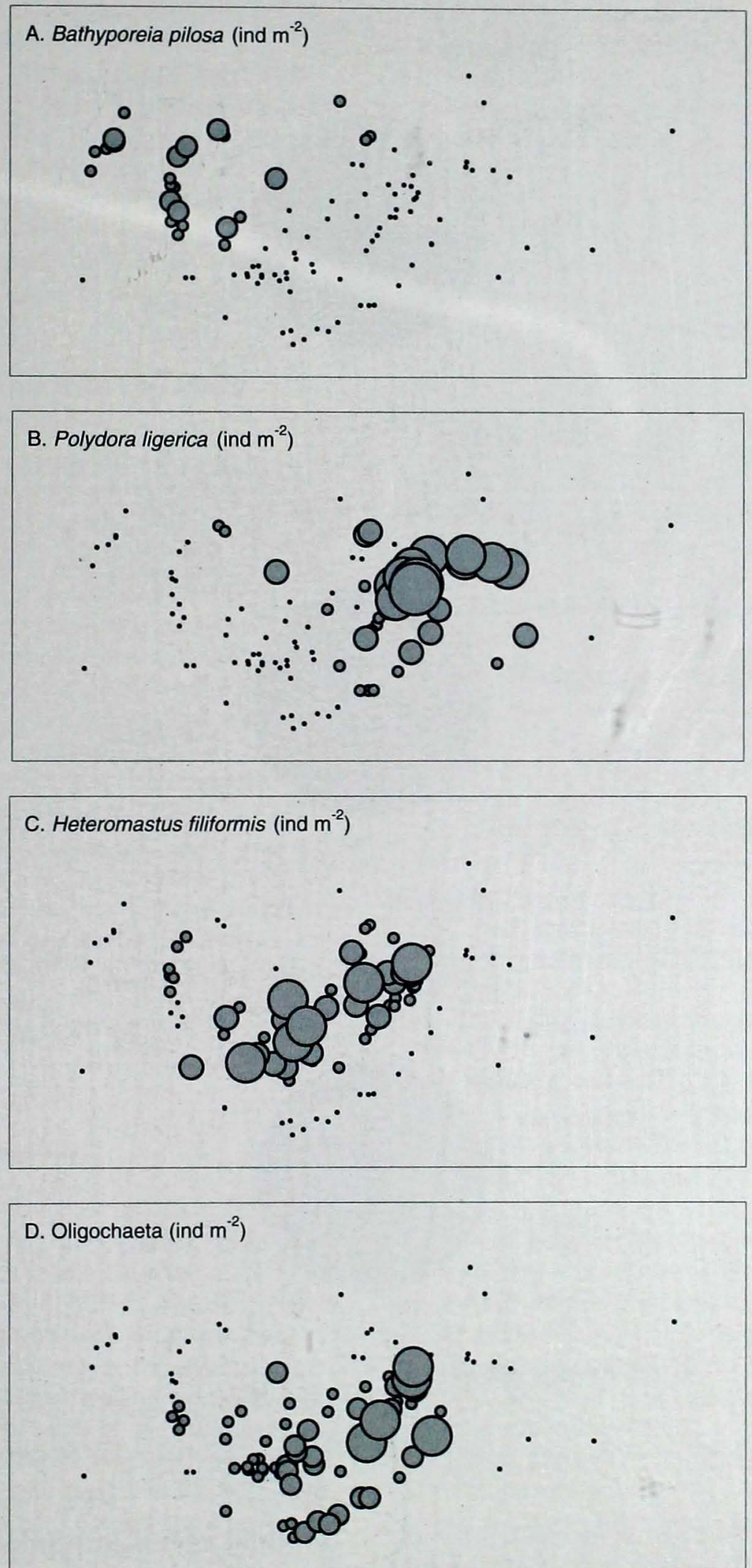

$\cdot 0$ ind $\mathrm{m}^{-2}$ o1-50 ind $\mathrm{m}^{-2}$ O $50-500$ ind $\mathrm{m}^{-2} \bigcirc 500-5000$ ind $\mathrm{m}^{-2} \bigcirc>5000$ ind $\mathrm{m}^{-2}$

Figure 7.7. MDS configuration from Figure 6 with circles scaled in size to represent individual species density of A. Bathyporeia pilosa, B. Polydora ligerica, C. Heteromastus filiformis and D. Oligochaeta. 


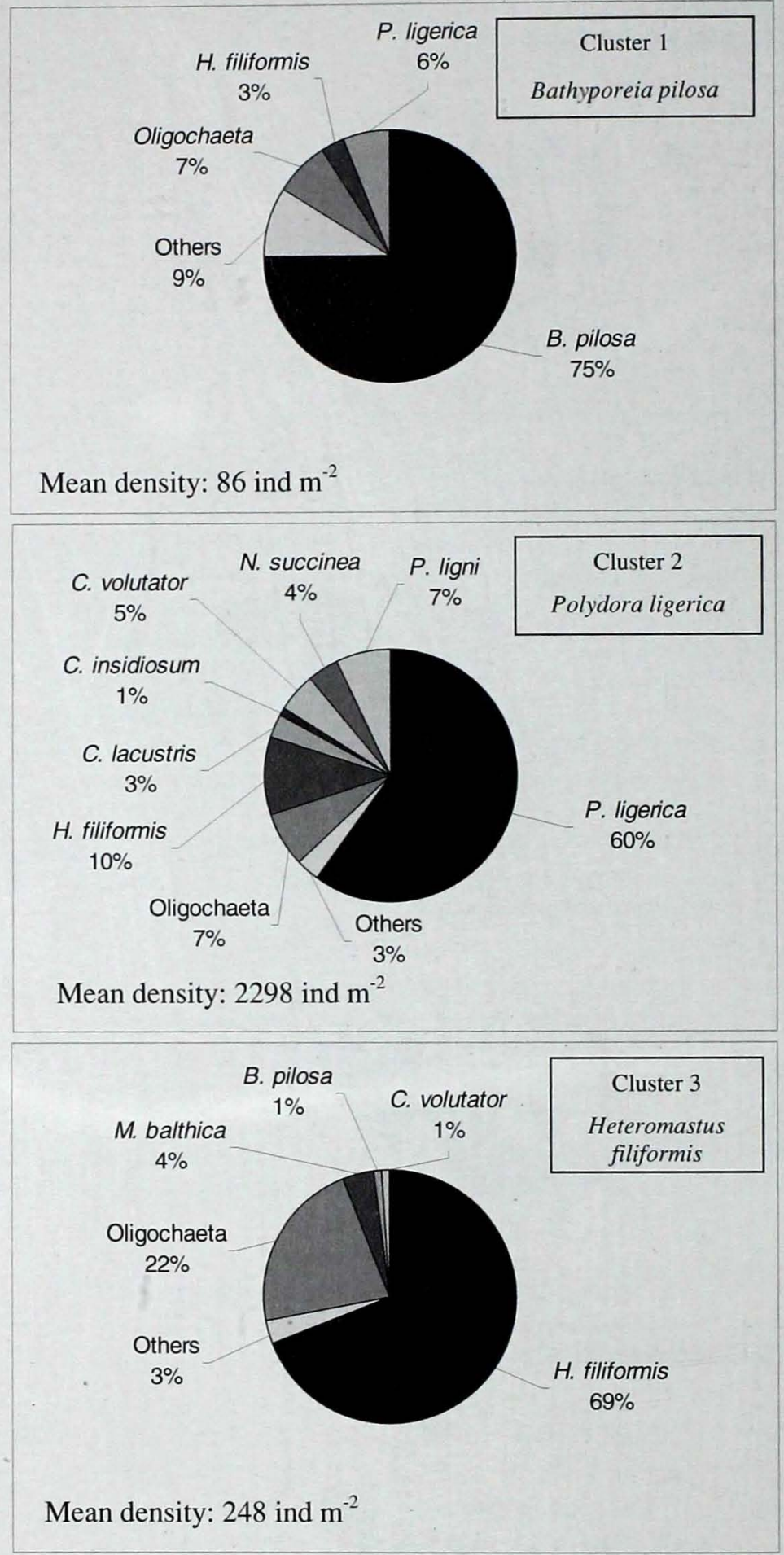

Figure 7.8. Mean species density per cluster based on density. data 1996 and 1997 together. For full species names: see Table 7.2.

remaining species were euryhaline and also occurred in the whole Westerschelde. The observation of Marenzelleria spp., an immigrant from North-American shores (BASTROP et al. 1997; ESSINK \& SCHÖTTLER 1997), and for the first time reported to occur in Europe in 1982 (MCLUSKY et al. 1993), is the most southern observation of Marenzelleria to date (YSEBAERT et al. 1996; ESSINK 1999).

\section{Subtidal versus intertidal macrobenthos}

The observed species richness of the subtidal zone of the Zeeschelde was higher than that of the intertidal zone, the densities and biomass however were lower. In a study from 1990-1996 on 24 intertidal locations within the study area, 24 species were found, five of which (Corophium volu- 
tator, Heteromastus filiformis, Nereis diversicolor (Müller), Macoma balthica and Oligochaeta) contributed to $96 \%$ of mean densities and $99,3 \%$ of mean biomass (pers. observ.). The same five species were also found subtidally, but generally at much lower densities. Polydora ligerica, the most abundant species of the subtidal zone of the Zeeschelde, was not found intertidally. Total mean intertidal densities were $7000 \pm 1060$ ind $\mathrm{m}^{-2}$, being dominated by $\mathrm{C}$. volutator (37\%) and total intertidal mean biomass was $4.79 \pm 0.34 \mathrm{~g}$ AFDW $\mathrm{m}^{-2}$, being dominated by $\mathrm{N}$. diversicolor (40\%).

\section{Historical comparison with LELOUP \& KONIETZKO (1956)}

The macrobenthos of the $\beta$-mesohaline part of the Zeeschelde has been studied in 1952 on 21 subtidal locations in the same area of the Zeeschelde (Leloup \& KONIETZKO 1956). At that time anthropogenic pressure was lower but water quality was already bad. The number of species in 1952 ( 15 species) was lower as compared to this study (35 species), but sampling effort was also lower. Eleven of the taxa were found in both studies. Some recently very abundant species, like Polydora ligerica and Heteromastus filiformis, were totally absent in 1952. The subtidal macrobenthic community in 1952 resembled cluster I of this study, being dominated by Bathyporeia pilosa, and showing low mean densities ( $85 \pm 24$ ind $\mathrm{m}^{-2}$ ). Communities of cluster 2 and 3 were nearly absent. As shown in this study, the occurrence of the community of cluster $\mathrm{I}$ is related to the presence of relatively coarse, sandy sediments. In 1952, the sediment was indeed coarser as compared with this study, as $70 \%$ of the sampling locations contained less than $5 \%$ of mud (fraction $<50 \mu \mathrm{m}$, determined by sieving).

\section{Human impacts}

The mesohaline subtidal zone of the Zeeschelde is by nature characterized by a high degree of 'unstability', caused by large fluctuations in salinity, high current velocities and high turbidity, making an assessment of human impacts on the benthic communities difficult. Human activities, such as the discharge of waste and dredging of sludge, are superimposed on these natural processes and, moreover, interfere with them. The combination of favourable hydrodynamic conditions, several fine suspended matter sources (including a large antropogenic part), and the flocculation process, leads in salinity zone 2-10 psu to bottom sediments that locally contain high percentages of fine material (BAEYENS et al. 1998). Being a major sedimentary environment, the shipping channel is extensively dredged. The processes of sedimentation and resuspension, at least locally, are probably enhanced by these dredging operations, that increased from $1 /$ million $\mathrm{m}^{2}$ dredged and 4 million $\mathrm{m}^{2}$ dumped in the period 1951-1960 to 20 million $\mathrm{m}^{2}$ dredged and 11 million $\mathrm{m}^{2}$ dumped in 1981-1990 (CLAESSENS pers. com.).

The fact that the subtidal zone of the Zeeschelde is a highly stressed environment was in this study confirmed by the very low density and biomass of the macrobenthos, and the most common occurrence of Heteromastus filiformis and tubificid Oligochaeta, small, sub-surface depositfeeding, opportunistic species. It was also clear from the $A B C$-curves that the communities considered were under stress. This provides strong evidence that the communities remain in early succession, and indicates stress or disturbance (e.g. WARWICK 1986; GASTON et al. 1998). The occurrence of three different macrobenthic communities in 1996-1997, two of which are typical for muddy sediments (clusters 2 and 3), might be explained by a difference in origin and magnitude of disturbance. A less common, typically low-diversity community (cluster I) was found on more sandy sediments, being dominated by the amphipod Bathyporeia pilosa, a well adapted inhabitant of unstable, sandy sediments (KHAYRALLAH \& JONES 1980). This community is characteristic for the mesohaline, subtidal part of the Schelde estuary, at places where by nature tidal current speeds and instability of the (sandy) sediment become the limiting factors (CRAEYMEERSCH 1999). It was also the only dominant community in 1952.

The dredging and dumping activities might have direct effects (being washed out, being buried) on the occurrence of macrobenthos. $70 \%$ of the samples taken at locations where intensive dredging took place (Figure 7.1 ) belonged to cluster 3 , dominated by the capitellid $H$. filiformis and tubificid Oligochaeta, which are known to be very tolerant to both physcial and chemical (organic enrichment, anoxia) disturbance factors (RAKOCINSKI et al. 1997; GASTON et al. 1998). Although most of the locations from cluster 2 and 3 occurred in silty sediments, species characteristic for cluster 2 (e.g. Polydora ligerica) were almost completely absent at dredging and dumping sites.

In the study area also several 'hard substrates' were constructed (e.g. dams, dykes, rubbles) to suppress erosion, to conduct the streamflow and for safety reasons. In many places these constructions subsided, causing the occurrence of stones and other similar hard substrates in the river, next to natural substrates like peat and shells. Most of the sediments with hard substrates were characterized by a high number of species and a relatively high density (cluster 2), although a lot of the samples taken were incomplete. Hard substrates can form a suitable habitat for several soft bottom species, as these substrates might provide shelter and prohibit species being washed out from the sediment. Balanus spp., often found in several layers on these hard substrates, might provide shelter for other animals, or create a multitude of habitats for other species, even for soft bottom ones, when silt is deposited in between (DITTMER 1983). The hard substrates also allowed the set- 
tlement of bivalves, like oysters. These suspension feeders could be considered an indication of improving water quality.

\section{Acknowledgements}

We are grateful for the financial assistance provided by the Ministry of the Flemish Community (AWZ) and for the logistical support by Ir.Taverniers, Ir.Wouters and the crews of the Veereman. Data on the model calculations for current velocities were provided by Ir. Harm Verbeek (RWSRIKZ) and Ir. Claessens provided data on the dredging and dumping activities in the Zeeschelde. We thank Nico De Regge and Jan Soors for their support in the field and in the laboratory. 